\title{
Chapter 2 \\ The Aliens in Us and the Aliens Out There: Science Fiction in the Movies
}

\begin{abstract}
Aliens fill us with dread and yet they exert an inescapable attraction on us. We shun them, we deny that they exist, but we can't get away from them-and no wonder: we don't necessarily recognize them when they're standing right in front of us. Aliens can assume familiar forms; they can look like members of our own family or our friends. They are familiar strangers. Or they can usurp humans like parasites, turning them into zombies. No one is immune. The distinction between what is out there-sometimes, as in the case of extraterrestrials, way out thereand what is within us begins to disappear.
\end{abstract}

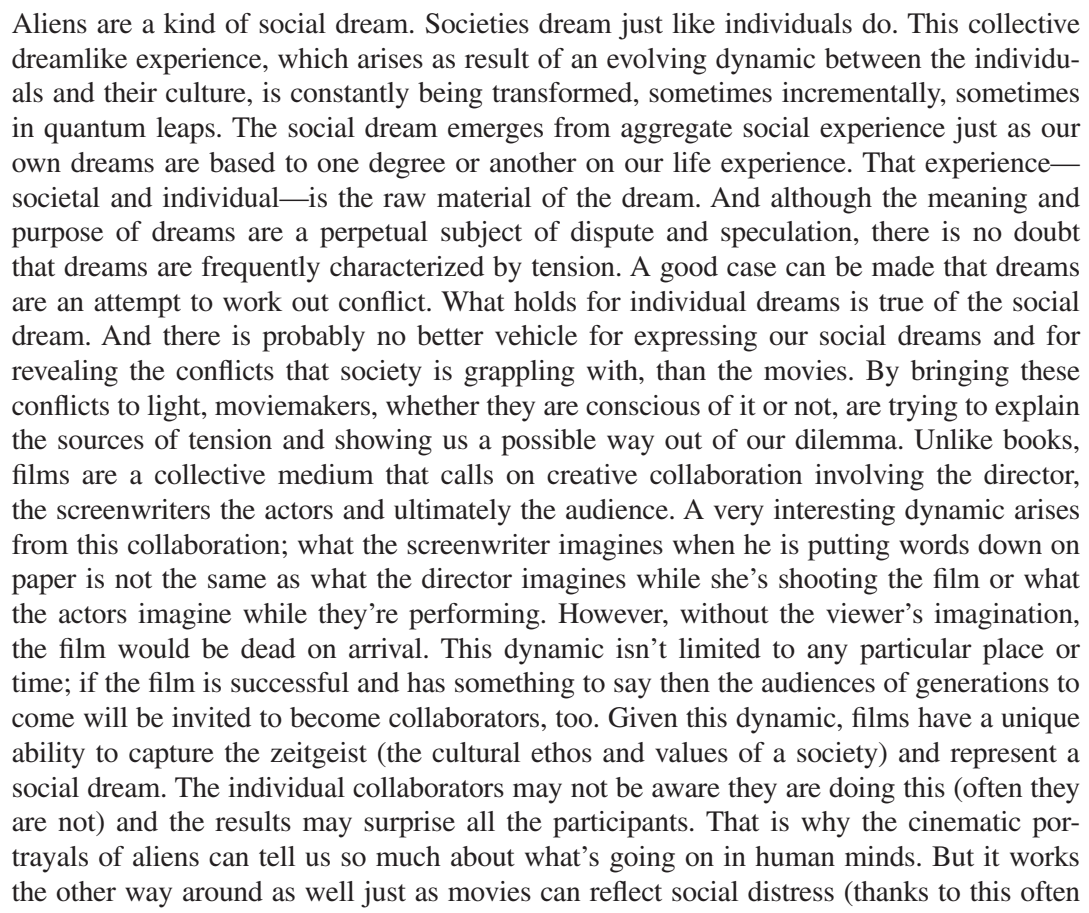


unconscious collaboration between filmmakers, writers, actors and audiences). They also have the capacity - and the power - to exacerbate social distress. Movies have been equated with dreams, since they employ the language of dreams to powerful effect. But movies can also provoke nightmares, too, and those nightmares don't necessarily end upon waking. Alternatively, they may just help to hypnotize us and keep us in the dark.

So if movies reveal a social dream, what can we say about social dreams in which aliens play a dominant role? What kinds of conflicts can potentially be resolved by a movie about aliens both benign (as in the 1982 "ET" film) or malevolent (as in the "Alien" series) The answer is...it depends. During the Cold War, social dreams were haunted by the specter of nuclear annihilation. If humans were perceived as incapable of settling disputes on their own we would require intervention by another life form with higher intelligence, capable of cleaning up the mess we've made. There is no better example than "The Day the Earth Stood Still" (1951) in which the alien Klatu (Michael Ronnie) shuts down all power for half an hour to demonstrate the consequences if humans don't reform their ways. Klatu is an obvious messiah figure; he is killed and then resuscitated by his robot Gort. (The robot is programmed to destroy the world if it doesn't hear the magic words uttered by the character played by Patricia Neal_-"Klatu barrada nikto.") "Join us and live in peace," As he prepares to return home Klatu warns humankind to change "or pursue your present course and face obliteration."

There are as many types of aliens as there are social dreams. Aliens can be clones (like those in "Blade Runner") or other outsiders like Frankenstein, Dracula, the werewolf, and the zombie. These beings meet the definition insofar as they occupy a state that isn't human but that isn't entirely not human, either (like another species); they aren't alive exactly but they aren't dead (or at least they aren't content to stay safely in the grave and decompose.) And while the majority of movies about aliens fall into a category we could loosely term "science fiction" they tend to be hybrids-a mixture of genres. Some movies, such as the Alien series, are essentially horror movies set in outer space. Others like "E. T." are really fantasies, fairy tales in which the "monster' may be misunderstood due to physical appearance and suspect origins. Still others like "Men in Black" (1997), notwithstanding its comic tone, are really mysteries. The Men in Black are purportedly CIA or FBI agents policing undercover aliens. According to conspiracy theorists, such creatures may produce officiallooking IDs which ultimately turn out to be fake or belong to people who are deceased.

Films in which aliens are the dominant figures (even if they lurk in the shadows or disguise themselves as ordinary human beings) almost invariably have an element of the mystery of detective genre. That is because alien life forms, assuming they exist somewhere in the cosmos, remain as much of a subject of speculation as ever in spite of all our efforts to detect their presence. Aliens hold the answer to the gnawing question that has preyed upon our minds since homo sapiens first emerged in the African savannah: are we alone in the universe? That is the ultimate mystery story. 
Aliens have a long and storied history, a history that runs parallel to and is rooted in our own. Aliens, after all, need a species to alienate or be alienated from. Aliens frequently enjoy a condition that humans can only aspire to-namely immortality. In these two first great civilizations of the ancient world, Egypt and China, the people believed in immortality and went to extraordinary lengths to try to achieve it. We have only to think of the pyramids or the necropolis of Qin in Xian, built by the first emperor of China. The direction that these two civilizations took to reach their goals was quite different-both literally and symbolically. Egypt took to the skies, or heavens, while China, went in the opposite directionunderground - in order to create their future home of immortality. (Qin's palace, guarded by a terracotta army and booby-trapped with arrows that could be triggered by intruders, still hasn't been completely excavated.) Both of these civilizations believed, and acted upon, their prime beliefs that you can take it with you! For the ancient Egyptians and Chinese these monuments, even if they were only intended for princes, potentates, and the highborn represented the ultimate means of coping with the perennial fear of death as well as serving a related purpose: namely, helping those peoples define the meaning of life. These are opposite sides of the same coin, as it were. Death is alien to life and life is alien to death. To the ancient Egyptians, the objective was to join or commune with the star gods or to travel, as it were, back to where it all began, to their origins. In their view, immortality amounted to a state of transcendence to an alien form of life but one that was both familiar and safe. In other words, the aliens out there turn out to be the aliens in us, too, that is, they reside inside our own human consciousness. Although these immortality-obsessed civilizations reached their pinnacle around $2000 \mathrm{BC}$, they are only one example of an age-old human coping mechanism in the face of mortality. It may be argued that in the current age we do this through movies.

From time immemorial we have been preoccupied with where we came from as a species, and where and when we die. That leaves us with the interval between the two extremes. Sir Francis Crick, who with James Watson won the Nobel Prize for his groundbreaking work on DNA, was partial to the idea that life might have first evolved from organisms that came from outer space. We are all composed of so-called genetic junk, whose purpose is still unknown. Is this evidence of our extraterrestrial beginnings? Regardless of the answer, we must side with Shakespeare when he wrote, "The fault, dear Brutus, is not in our stars, but in ourselves." Shall we look back to our future, or look ahead to our past? Metaphorically speaking, the past is in some measure the present and is part of the past; but tomorrow is forever. All of this is what the contemporary myths in films about the aliens tell us. Or put another way: Are the gods of the human race within us or outside of us, or is it necessary to have a concept of god at all? The great medieval philosopher Meister Eckhart said, "The more God is in all things, the more he is outside them" although he was careful to add: "God is within more than without." The equation of gods and aliens isn't simply a bit of rhetorical sleight of hand. Sometimes in movies, aliens behave more like the capricious gods of ancient Greece. In “The 27th Day" (1957), for example, aliens plan to wipe out humanity but decide to let their victims do their work for them by giving five 
people capsules capable of destroying a continent, then withdraw from the scene to watch the ensuing disaster from afar. This state of affairs recalls Pogo's famous saying that we have met the enemy and he is us.

Our fascination with aliens may, to a large degree, derive from our own alienation. As the distinguished psychologist George Miller observed in his inaugural address to the American Psychological Association in the 1960's "People are growing increasingly alienated from a society in which a few wise men behind closed doors decide what is good for everyone.... Even those most blessed by economic rewards are asking for something more satisfying to fill their lives... Anyone who reads the newspapers must realize that vast social changes are in the making, that they must occur if civilized society is to survive." What filmmakers are doing - although they are seldom conscious of it-is playing upon the awe and fear that these "few wise men behind closed doors" evoke, transforming them by the magic of cinema into the alien beings who exercise powers that are denied ordinary human beings. "Vested interests will oppose these changes, of course," Miller goes on, "but as someone once said, vested interests, however, powerful, cannot withstand the gradual encroachment of new ideas." Almost invariably, the intervention of aliens in our world upends the established order (how could it not?) Even when we defeat the aliens and send them packing (if we haven't obliterated them first) things have changed irrevocably. Just think of what will happen when scientists announce that they have discovered life on another planet, as they probably will someday; even if that life form is microbial, it will inevitably compel us to readjust our conception of the cosmos and our place within it. In that sense, films in which aliens play a role allow us to stage dress rehearsals in our minds for the possibility that one day aliens will walk among us, if they aren't already.

Some readers will recall the popular books of Erich von Daniken who postulated that gods did in fact arrive on our planet eons ago in spaceships. His theories may be far fetched, but he managed to tap into a general feeling that superior beings like Klatu may have visited Earth more than once in the past and set things in motion (an idea that Kubrick also exploits in his 1968 classic "2001"). The "Stargate" franchise (launched by MGM in 1994) was based on the premise that aliens infiltrated the Earth many years ago through a wormhole created by a ringshaped alien device (the Stargate of the title) and have been walking among us for years. And we all know what happened when aliens attacked us in H. G. Welles' "War of the Worlds" (made into a film in 1953 and again in 2004) where the alien invasion culminates in a takeover of our planet, proving that if they could push the start button aliens also have the capacity to press the stop button as well.

The first cinematic alien appeared, improbably, in "The Man in the Moon in Santa Claus' Busy Day" (1906) followed 2 years later by a sequel "The Man in the Moon Seeks a Wife." Although aliens don't make much of an appearance in the famous expressionist films produced in Germany between the wars their presence can still be felt. The machine city in "Metropolis" (1926), for example, could as well have been operated by aliens as by subjugated proles; indeed, that is the point: for the ruling class the slave laborers are aliens. Significantly, "Metropolis" features a female robot, carrying on a tradition that began with Joseph Melies 
who pioneered the use of robots in film "The Clown and the Automaton, 1987." Robots and androids are simply aliens in another guise, the main difference being that humans are responsible for their creation. However, in almost every film in which these artificial creations occur they tend to become autonomous, blurring the boundary between human and machine. HAL, the malevolent supercomputer in "2001," still epitomizes the threat of technology run amok. Worse: doubt is cast as to whether it hasn't become a sentient being in its own right when, upon being dismantled, it complains that it can "feel" the destruction it is undergoing. At this point HAL sings the song, 'Daisy, Daisy, Give Me Your Answer True,' which in an inside reference turns out to be the song used in a test for the Voice-Coder, a pioneering voice replication device created at Bell Labs. The song was also used in a nightmarish fashion in the 1954 trilogy directed by Orson Welles called "Three Faces of Murder." It should also be noted that when the villain is finally revealed at the conclusion of "The President's Analyst" (1967) it turns out to be an android at Bell Labs, which for many years was the premier technological research lab in the country. That the President of the United States would require an analyst wasn't some farfetched notion, either. Kenneth Clarke, in an inaugural address to the American Psychological Association proposed that an elite group of enlightened psychiatrists, mental health specialists, and neuropharmacologists should assume the administration of a program of "direct psychotechnological intervention" for political leaders to "assure their positive use of power and reduce or block the possibility of their using it destructively." It is unlikely that even if such a utopian project were implemented the proposed beneficiaries would be inclined to undertake a "type of internally imposed disarmament."

Understandably, we begin to think of our minds as if they are computers (when, in fact, they are infinitely more complicated than even the most sophisticated computers). But from that perspective, we feel that it's only a matter of time before the computers we build today will eventually create other computers with the power to take us over. (Computers are already capable of innovation that allows them to create smarter computers without human intervention.) As we surrender more and more of our lives to technology we become ever more unsettled about the forces we are unleashing. We feel that we are relinquishing control. In other words, we feel alienated from our own inventions-worse, we feel that we are becoming machines. "Closely related to this emphasis on control," George Miller writes in his American Psychologist essay, "is the frequently repeated claim that living organisms are nothing but machines. A scientist recognizes, of course, that this claim says far more about our rapidly evolving conception of machines than it says about living organisms, but this interpretation is usually lost when the message reaches public ears. If the assumption that behavior control is feasible becomes and accepted concept, it could have unfortunate consequences, particularly if it is coupled with an assumption that control should be exercised by an industrial or bureaucratic elite" Miller (1969). Sometimes this 'elite' can be a single individual. That is the case in another famous film from Weimer Germany featuring the "masterful hypnotizer"-_Dr. Caligari." As the noted critic Siegfried Kracauer puts it in his introduction to the script: "Caligari is a very specific 
premonition in the sense that he uses hypnotic power to force his will upon his tool-a technique foreshadowing, in content and purpose, that manipulation of the soul which Hitler was the first to practice on a gigantic scale. Although, at the time of Caligari (1920), the motif of the masterful hypnotizer was not unknown on the screen....nothing in their environment invited the two authors (Janowitz and Mayer who wrote the screenplay) to feature it. They must have been driven by one of those dark impulses, which, stemming from the slowly moving foundations of a people's life, sometimes engender true visions." (Janowitz and Mayer 1972) Caligari, like the aliens, reflects the unconscious fears and longings of society, but he also foreshadows events that these fears and longings may bring into play. "Whether intentionally or not, Caligari exposes the soul wavering between tyranny and chaos, and facing a desperate situation: any escape from tyranny seems to throw it into a state of utter confusion. Quite logically, the film spreads an allpervading atmosphere of horror. Like the Nazi world, that of Caligari overflows with sinister portents, acts of terror and outbursts of panic. The equation of horror and hopelessness comes to a climax in the final episode, which pretends to reestablish normal life" (Janowitz and Mayer 1972).

We find a similar phenomenon in films in which aliens function as surrogates for those elites who, for one reason or another, stand outside of society, who are both reviled and feared, who are regarded as both inferior and superior and whose powers threaten our own independence and dignity. We are afraid of what these hypnotizers or wielders of excessive influence (whether robots, aliens or fuhrers) can do because we fear that we are all too ready to give them the power that relieves us of the responsibility for our own fates. As Krakauer observes about Caligari "The normal as a madhouse: frustration could not be pictured more finally. And in this film...is unleashed a strong sadism and an appetite for destruction. The reappearance of these traits on the screen once more testifies to their prominence in the German collective soul (Mayer 1972)." In movies aliens testify to the appearance of such traits in the collective soul of every one of us.

The heyday of the alien occurred in the 1950s. In the 1951 film "The Man from Planet X" audiences were introduced to what critic Donald Gifford calls "the first of many misunderstood monsters" that don't fare well on the planet they invade. It wasn't until 1953 that aliens made their screen debut in color-unsurprisingly it was green. These green creatures were controlled by "the ultimate brain of all," a tentacle head in a globe (prefiguring Dennis Potter's TV movie "Cold Lazarus" in which a man's head is kept functioning so it can deliver oracular pronouncements). In "Invaders from Mars," the 1953 film version of H. G. Wells' The War of the Worlds, Martians descend on Los Angeles, but their technology is no match for ours: they use heat rays while the US Army uses atomic bombs. (No doubt because of its proximity to so many movie studios, LA remains a favorite spot for aliens to launch their invasions; at least two movies in 2011 feature an alien invasion of LA.) When atomic weapons won't do there's always a fallback position: brain power. In the 1955 film "This Island Earth," human brains are appropriated to protect against aliens, producing the Mutant, "a clawed creature with an enlarged and exposed brain, apoplectic eyes and five interlocking mouths." 
(Gifford 1972). The Mutant, though, had nothing on the villainous creature in "It Conquered the World" (1957), which depicted "one of the most alienating aliens, a kind of creeping cone which flung forth flying bats." (Gifford 1972) In "Village of the Damned" (1960) twelve women are impregnated during a mysterious blackout. On reaching the age of nine, the offspring combine their brains in a plot to dominate the world.

In many films humans are culpable in setting aliens loose on the world, reminding us that just as curiosity killed the cat it could kill us, too. In "The Thing" (1951), a spacecraft is discovered buried under the ice in the Arctic. By thawing out the dead pilot, scientists inadvertently unleash a blood-sucking alien on the world. A similar theme is echoed in "The Quatermass Experiment" (1955). The protagonist (Richard Wordsworth) is the sole survivor of a rocket contaminated by a space organism; once he becomes infected he turns into a grotesque version of King Midas, only instead of gold, he absorbs life from whatever he touchesanimal, vegetable, or human, so that he finally turns into a hideous monster who meets its unlikely demise by electrocution in Westminster Abby. These cautionary tales seem to be inspired, however, indirectly, by the myth of Pandora's Box. The filmmakers were surely aware that by splitting the atom scientists had popped open the ultimate Pandora's Box and that the radiation from the atomic explosions in Hiroshima and Nagasaki had produced more than a few human monsters, not all of them were the victims on the ground.

Aliens are not always treated as malevolent beings that have come to usurp our bodies or seize control of the planet or pilfer its resources. In the 1988 "Alien Nation," the aliens known as 'Newcomers' are gradually integrated into society once the shock of their initial contact wears off. However, they begin to suffer from increasing discrimination, providing a convenient metaphor for racial tensions. The 2009 "District 9" also depicts aliens in a sympathetic light; forced to take refuge on Earth after a mechanical failure strands their spaceship, they are herded into internment camps where they are exploited by their supposedly more enlightened human captors. It is significant to note that the film-a worldwide box office success - was shot in South Africa.

Knowing the animosity and suspicion that they can arouse, aliens, however, benign their motives, often take pains to camouflage their true nature. In some cases a disguise is essential if the alien is to accomplish its purpose on Earth. That is certainly the case of Superman. Like many messiahs in religion and mythology, Superman has his weakness (kryptonite); concealing his alien origins, he conceals himself in the guise of a human, Clarke Kent. Superman, who began life in the 1930s in comic books before taking a star turn in any number of films and a TV series, exemplifies the alien as savior. Superman is an alien archetype that may be referred to as a perennial or a recurrent social dream. That is to say, he represents a kind of timeless myth that resonates in whatever period or place he alights. (His sinister counterparts in "War of the Worlds" are also perennials.) Perennials are to be distinguished from the aliens whose portrayals differ from one period to another because of changing political, cultural, or economic conditions. These aliens are products of the zeitgeist. The zeitgeist reflects generational 
paradigm drift rather than a shift; trends generally overlap and change incrementally. Arguably, Superman is the most powerful representative of a social dream in this context insofar as he reflects a particularly American need and longing for a savior, whether it's religious or political or comes from outer space. The enduring appeal of Superman can also be seen in the way he's portrayed from one generation to another and from one medium to another spanning comic books, movies, and television. In one of his latest incarnations the man of steel was depicted in his formative years in the TV series "Smallville," a successful effort to make a perennial figure appealing to a younger generation.

In James Cameron's 1984 "The Terminator" (which spawned a profitable film and TV franchise) the 'aliens' are cyborg assassins (Arnold Schwarzenegger) confronting a human resistance fighter (Michael Biehn) who is hunting them down. The catch is that both assassins and his pursuers come from the future. What is at stake is nothing less than the world's fate. The object of their time travel is Sarah Connor (Linda Hamilton) whose future son (if she survives long enough to give birth) is destined to lead the struggle against a cyborg takeover several years hence. It's as if a Roman soldier and a priest from the first century had returned to the past in an attempt to either slay or save Mary before she gave birth to Jesus. Interestingly, the cyborg is a product of human ingenuity, not an extraterrestrial marauder; so in that sense we have met the enemy (read alien) and once again he turns out to be us all along.

Many people firmly believe that aliens are out there watching us—aliens who are looking out for us and aliens who may not have our best interests at heart. For some the idea of benevolent aliens is akin to a religious belief system wherein an omnipotent god is taking care of things. Films have reflected this viewpoint. Stephen Spielberg's 1976 "Close Encounters of the Third Kind" is illustrative. As the Bible reminds us, "many are called but few are chosen." In this instance the 'chosen' one is an electric lineman named Roy who after being lured to the landing site of dozens of UFOs is welcomed on board the mothership and invited to accompany the aliens back into space. Musical sounds emitted by the spacecraft can even be seen as "The Bells of Saint Mary's" calling you to church except that an alien five-toned signal takes the place of the bells. Although the nature and motivation of aliens can change with the zeitgeist the religious element persists from one generation to the next. We can even think of angels as a species of aliens. Not so many years ago angels enjoyed a kind of resurgence; rather than counting the number of them on the head of a pin it was possible to count the number of books about them in your local bookstore. (The totals might not have been too different.) Of course, angels have their counterpart in demons; the former come from above (the ancient Egyptian model) while the former emerge from below (the Chinese). That a religious association frequently attaches itself to aliens is perfectly understandable; it's human nature that's driving it. The history of human beings is characterized by a need to believe in something and for many people aliens are as good as gods or alternatively, identical to them as von Daniken postulated. As Kenneth Clarke observes in an essay entitled The Pathos of Power: A Psychological Perspective, man created God for "purpose and substance," and 
it is for this reason that man cannot allow God to die. "If God were to die, human beings would have to die psychologically, even though alive as organisms." God, Clarke declares, also serves as "a protection against the fragility of the human ego, which led to such compensatory protective agents as "demigods, the directly observable gods" as well as "magicians, medicine men, priests, bishops, kings, generals, father figures, movie stars," which he maintains, all "serve similar if not identical divine functions." These "personifications of power" are given virtues and powers beyond those found in ordinary men." By identifying with them and their projected power, "the average man can obscure his weaknesses and affirm his ego" (Clarke, X). But in our secular age we have imbued extraterrestrials with many of these same superhuman attributes. Aliens then can, at least on screen, assume the same privileges and shamanistic role as those medicine men, bishops, kings, and gods. The power they can project is limited only by our imaginations.

If the prospect of imminent destruction is a chronic source of anxiety for humankind, the causes differ from generation to generation. So the prospect of nuclear catastrophe has ebbed while that of environmental calamity has grown. Rachel Carson's Silent Spring, published in 1962, focused attention on this problem, specifically regarding the negative effect of pesticides. Although the nature of the threat to the environment has changed-from the perils of DDT and to the perils of climate change - the gnawing sense that the world is deteriorating has only grown. Not surprisingly, aliens have a part to play in the degradation of the environment. It turns out that aliens do not always have to come from outer space. In the 1960 low-budget "Little Shop of Horrors" (which enjoyed a second life in a cinematic musical version released in 1986) the alien takes the form of a malevolent plant. The film begins with an ominous prologue delivered by Shirley Jones: "On the twenty-third day of the month of September, in an early year of a decade not too long before our own, the human race suddenly encountered a deadly threat to its very existence. And this terrifying enemy surfaced, as such enemies often do, in the seemingly most innocent and unlikely of places..." The improbable hero Seymour Krelborn works as an assistant in a florist shop. Among his plants is one that resembles a Venus flytrap, which he names Audrey II in honor of a girl he has a crush on. But instead of being content with water and plant food, Audrey II has a voracious appetite for human blood, which it satisfies with increasing frequency throughout the course of the movie. "Little Shop" was by no means the first film to emphasize the alien nature of plants. In "The Day of the Triffids" (1963), a meteor storm blinds the human population and endows plants with humanlike intelligence, allowing them to infest London.

In some films like the "Alien" series, the first of which was directed by James Cameron and released in 1986, the aliens act like parasites, infiltrating and ultimately destroying their human hosts. Similarly, in "The Invasion of the Body Snatchers" (its first iteration appeared in 1956) humans are taken over by plant forms (pods) with the knack of simulating the individuals they destroy and assuming their identities. The film, directed by Don Siegel, was based on Jack Finney's novel which featured space plants "that blossom into 'blanks' which take on the shape of humans, then take their places...." (Gifford 1972) To some degree, these 
films suggest that the fear of the unknown has shifted from the external (predatory extraterrestrials threatening us from the skies) to the internal (the microbial). By the late $1970 \mathrm{~s}$, an era of increasing eradication of infectious diseases came to an end. With such "new" diseases as Legionnaire's Disease, SARS, West Nile Virus and especially HIV/AIDS, the routes and vectors of infection had multiplied enormously. The dread that AIDS inspired was amplified by its unclear etiology and lack of effective treatment. That its first victims were predominantly gays, minorities, and drug users - e.g., often treated as if they were aliens-made it all the more terrifying and delayed the search for a cure.

Sometimes, though, aliens are regarded as equals - as just one of the guys. Nowhere do we see this democratic spirit exemplified more than in "Star Trek" and especially in "Star Trek: The Next Generation," where aliens and humans make up the crews of the Starship Enterprise. In "Next Generation" one crew member, Lieutenant Commander Data is an android and another, the tactical officer Worf is a Klingon. Regardless of their origin, they are all united in fealty to their prime directive-an injunction not to interfere with the evolution of any society or civilization on any planet. Here is a case where the television and cinematic depictions of aliens reflect not dread or terror of society but rather its highest aspirations. The Starship Enterprise's crew is a microcosm of a United Nations; earthlings and aliens are up against the same galactic threats and must confront the challenge together if they are to survive. The prime directive conveys a not-so-subtle anti-colonial and anti-imperialist message to be sure, but it can also be interpreted as a warning to countries to think twice before using force on recalcitrant adversaries. "Star Trek," in both iterations, represents a social dream, but a dream that can change depending on the circumstances. If the original series reflected the social distress of the Cold War, "The Next Generation" taps into the fears stirred by terrorism.

The staggeringly successful 2009 film "Avatar" directed by James Cameron seems to equate aliens with indigenous peoples who even in a post-colonial world remain liable to exploitation. The Na'vi, natives of the lush moon Pandora, while technologically unsophisticated, are leaps and bounds ahead of their would be exploiters when it comes to spiritual matters. They represent a paradise that we've lost on Earth and seem to be hell-bent on destroying wherever else we might find one in the rest of the universe in the name of profit. As George Miller observes in his essay for The American Psychologist: "When the evolution of species was a new and exciting idea in biology, various social theorists took it up and interpreted it to mean that capitalistic competition, like the competition to successfully adapt to the environment, was the source of all progress, thus justifying the great wealth of the new industrialists" (Miller 1969). Although social Darwinism is now discredited, it retains its influence, suggesting in the context of "Avatar" that it isn't the Na'vis who are the aliens. It is us.

It would be a mistake to consider the subject of aliens without taking into account a trinity of affinities that are not usually classified as such. For example Frankenstein, the Wolf Man (or Werewolf) and Dracula and the distinguished line of vampires that have followed in his blood-drenched wake are perennial 
creatures, e.g., they have a powerful hold over the imagination irrespective of the epoch in which they appear although there are understandable differences in the way they are depicted form one period to the next. The three beings are weird hybrids, occupying an ambiguous position between the living and the dead, the human and the animal, the mortal and the immortal. They inspire both dread and fascination. (Certainly the recent appeal of vampire novels and movies like "The Twilight" series attests to the enduring obsession with vampires.) The Wolf Man or werewolf embodies all that is untamable and uncontrollable, the beast within us all. The original Wolf Man, played by Lon Chaney, Jr. in the 1941 film of the same name, is infected with a terrible disease because of a gypsy curse. A sympathetic priest shelters the young man in his church but warns him that the only way he can avoid the effects of the curse is to remain inside the church. As soon as he steps outside he is at risk of being turned into a beast, and of course, he does. His attraction to a beautiful peasant girl proves too much of a temptation to resist. It is notable that the Wolf Man suffered from being raised by a distant father who never appreciated him. The priest effectively became a father surrogate, but cannot prevent the curse from coming to fruition.

Of the three, though, Frankenstein may have the most relevance for contemporary society since he represents an attempt by science to create new life forms, which, after all, is one of the principal objectives of current scientific research (Chimeras are the name given to genetic hybrids). One might say that to one extent or another three of these creatures embody the concept of the living dead. While the Diagnostic and Statistical Manual of the American Psychiatric Association classifies psychiatric afflictions using an elaborate system of categories, this trinity of affinities does much the same thing on a metaphorical level; Frankenstein, Dracula, and the werewolf represent forms of mental illness and in that sense pose a perpetual challenge to our ability to maintain a sound mind and body in a humanistic society.

While Frankenstein's creature, like the vampire and the werewolf, has been featured in enough movies to fill a lifetime of Saturday matinees, we would be remiss if we ignore another variation of the myth-indeed, an extension and elaboration of the myth - namely Dr. Donovan's brain. If "2001" reflects the zeitgeist of the Seventies, and "Alien Nation" reflects currents in the Nineties, "Dr. Donovan's Brain," based on a novel by Curt Siodmak, taps into the fears and uncertainties of the postwar era. Dr. Donovan was a real person-significantly, a phrenologist, who published a book about his research in the late Nineteenth century. ${ }^{1}$ Several years later Slodmak's novel appeared under the title "Dr. Donovan's Brain," followed shortly by a film version of the same name written and directed by Felix Feist (It is hard not to believe that the real Dr. Donovan wasn't an inspiration). Once again the story revolves around an experiment that has every potential of going horribly wrong. Dr. Patrick Cory, the protagonist, has obtained a rhesus monkey for his research. At the outset he cautions his wife not to get too attached to the animal since he intends to destroy it for science. Dr. Cory doesn't need to worry about government approval for his research; he's independently wealthy and

1 Dr. Donovan (1942). 
operates his own lab in an isolated community where there's little risk of prying neighbors. He and his assistant remove the monkey's brain and put it in a fish tank. To their delight, the brain still shows sign of electrical activity. At that point there is a call from the police. A small plane has crashed nearby and there is only one survivor who is badly injured. Dr. Cory tries to treat this man who dies in spite of his efforts. Inspired by his success preserving the monkey's brain, Dr. Cory decides to see if he cannot keep the pilot's brain going as well. How to communicate with the brain remains a problem until Dr. Cory has an inspiration: he will try telepathy. But the brain he's determined to keep alive turns out to belong to the notorious W.H. Donovan, a ruthless millionaire. Dr. Cory proves no match for the brain, which takes control and uses him to murder the not-so-late Donovan's enemies.

That interest in aliens and what havoc they can wreak (or what lessons they can teach us) continues to run high is indisputable. Viewers have the opportunity to watch recently released films such as "Cowboys and Aliens," "Battle Los Angeles," (aliens invade the streets of LA), "Skyline: (aliens invade LA yet again), "Battleship: (based on a board game in which various life forms come to our planet for some mysterious purpose), "Alien 5" (the latest in the franchise), "Area 51: (teens sneak into the secret facility at Roswell), "The Darkest Hour" (tourists trapped in Moscow after an alien invasion), and three sequels-"Avatar 2," "Cloverfield 2," and "District 10." TV screens will be filling up with aliens too. $V$, about an "Independence Day" scenario with nice aliens for a change, is a hit and the forthcoming Fallen Skies, will follow a group of human resistance fighters as they carry out a guerrilla campaign against alien invaders.

In real life, a muted but still vigorous debate is ongoing as to how or whether we should communicate with aliens in the event that they decide to get in touch. In a recent television documentary the eminent physicist Stephen Hawking weighed in with an opinion that stunned many scientists as well as lay people when he said that we should remain silent if extraterrestrials do make an attempt to contact us, adding that we should not be trying to find them, either. He has no doubt that something is out there. Given the billions of galaxies, Hawking contends that life must exist somewhere else. "To my mathematical brain, the numbers alone make thinking about aliens perfectly rational," he said. "The real challenge is to work out what aliens might actually be like." Although the extraterrestrial life forms will probably be microbe-like or simple animals, he noted, there is always the possibility that they will be intelligent-more intelligent than us. And that could pose a problem. "We only have to look at ourselves to see how intelligent life might develop into something we would not want to meet," Hawking said, "I imagine they might exist in massive ships, having used up all the resources from their home planet. Such advanced aliens would perhaps become nomads, looking to conquer and colonize whatever planets they can reach." So making contact with aliens would be "a little too risky," adding, "If aliens ever visit us, I think the outcome would be much as when Christopher Columbus first landed in America, which did not turn out very well for the Native Americans" (Leake 2010). 
The United Nations Office for Outer Space Affairs (an actual agency based in Vienna) has kept a low profile when it comes to this issue. The Office, which is mainly concerned with monitoring space debris of human origin, was recently in the news when it sponsored a conference in Britain in which panelists debated such topics as "Calling ET, or Not Even Answering the Phone?" and "Extraterrestrial Life and Arising Political Issues for the U.N. Agenda." Like Hawking, Martin Dominik, a physicist at the University of St. Andrews and the organizer of the conference, believes that if it's discovered, alien life is likely to be microbial or announce itself in an electronic signal. "There could be interaction between life on our planet and life elsewhere so how do we deal with that," he said. "The question is should we send messages into outer space or not? Is this dangerous? Should we make ourselves visible to extraterrestrial life or not as a means of identifying ourselves? If they know we are here, do they want to destroy us? Will they help us? Do we gain something from that? These are all open questions." (MacFarquhar 2010) Given the limited success humans have had so far in getting our own house in order-from ending wars to addressing climate changethese questions are likely to remain open for a good long time, barring the return of Klatu who might decide to solve our problems once and for all.

\section{References}

Clarke, K. (1971). The pathos of power: A psychological perspective. American Psychologist, 26(12):1056.

Gifford, D. (1972). Science fiction film. New York: Studio Vista, dutton pictureback.

Janowitz, H., Mayer, K., Kracauer, S. (1972). The cabinet of Dr. Caligari. New York: Simon \& Schuster.

Leake, J. (2010). Don't talk to aliens, warns Stephen Hawking. The Times. 25 April 2010. http://www.timesonline.co.uk/tol/news/science/space/article7107207.ece.

MacFarquhar, N. (2010). UN weighs how to answer a knock on Earth's door. The New York Times, 8 October 2010. http://www.nytimes.com/2010/10/09/ world/09nations.html?_r=1\&scp=1\&sq=extraterrestrials\%20UN\&st=cse.

Miller, G. (1969). Psychology as a means of promoting human welfare. American Psychologist, 24(12), 1063.

\section{Notes}

Miller, G. (1969). Psychology as a means of promoting human welfare. American Psychologist, 24(12), 1074.

Clarke, K. (1971). The pathos of power: A psychological perspective. American Psychologist, $x$, $1055-1056$.

Miller, G. (1969). Psychology as a means of promoting human welfare. American Psychologist, $24,1068$.

Janowitz, H., Mayer, K., Kracauer, S. (1972). The cabinet of Dr. Caligari. New York: Simon \& Schuster, p. 22.

Janowitz \& Mayer, 23. 
Janowitz \& May 4, 24.

Clarke, 1054.

Gifford, Dennis. Science Fiction film. New York: Studio Vista, Dutton Pictureback, 1972, 87. Gifford, Dennis, 87.

Gifford, Dennis, 89.

Miller, George, 1068. 